\title{
Role of Portal Hemodynamics in Mortality and Adverse Out- come Prediction of Hyponatremic Cirrhotic Patients
}

\author{
Nagla Abd Al Monem ${ }^{1,8}$, Samir A. Afifi, ${ }^{2,8}$, Samar S. Ahmed ${ }^{3,7}$, Dalia Ghareeb ${ }^{4,7}$, \\ Rehab M. Ateya ${ }^{4,8}$, Ahmed A. Bessar ${ }^{5,8}$, Fatma Rageh ${ }^{6,7^{*}}$
}

Departments of Tropical Medicine ${ }^{1}$, Internal Medicine ${ }^{2}$, Community, Environmental and Occupational Medicine 3 , Clinical Pathology ${ }^{4}$, Radio-diagnosis 5 , Infectious Diseases, Gastroenterology and Hepatology ${ }^{6}$. Faculty of Medicine, Suez University ${ }^{7}$, Faculty of Medicine, Zagazig University ${ }^{8}$, Egypt

\begin{abstract}
Background: Cirrhotic patients have variable degrees of hepatic dysfunction. Impaired portal hemodynamics and hyponatremia occurs in the setting of end-stage liver disease. Aim: to uncover the role of portal hemodynamics in mortality and adverse outcome prediction of hyponatremic cirrhotic patients. Subjects and Methods: Eighty cirrhotic patients with hyponatremia (serum $\mathrm{Na}<130 \mathrm{mmol} / \mathrm{L}$ ) were included. diagnosis of hepatic encephalopathy using West Haven criteria, laboratory investigations, modified Child-Pugh and MELD scores were calculated, abdominal ultrasonography with Doppler study of portal circulation and upper GIT endoscopy were performed and the patients were followed up during their stay in hospital. Results: Serum sodium level has high statistically significant negative correlation with modified Child-Pugh score $(P<0.001)$ and with MELD score $(P<0.001)$. Most of the patients developed hepatic encephalopathy, spontaneous bacterial peritonitis, hepato-renal syndrome, and bleeding recorded in some patients; meanwhile mortality in $10 \%$ of the patients. In addition, apart from Hepatic Artery resistive Index, the difference in MELD score, MELD-Na score and Portal vein congestive Index between non-survived and survived patients was statistically insignificant, although all these indices were highly significant with hepatic encephalopathy, Portal vein congestive Index is highly significant in hepato-renal syndrome and bleeding esophageal varices, and Hepatic Artery resistive Index is highly significant in hepato-renal syndrome. Analysis of the receiver operating characteristic curve revealed that Portal vein $\mathrm{Cl}$ was the most sensitive indicator (sensitivity 78.5\%) and hepatic A resistive Index was the most specific indicator for prediction of mortality in hyponatremia cirrhotic patients. Conclusion: portal vein $\mathrm{Cl}$ and hepatic A. RI can be used in the prediction of mortality in hyponatremia cirrhotic patients.
\end{abstract}

Keywords: Hyponatremia, Portal hemodynamics, Portal vein congestive Index

\section{Introduction}

In Egypt, liver diseases are common with multiple etiologies including Parasitic, viral, bacterial, and metabolic causes. In the Egyptian demographic health survey, the estimated percentage of liver diseases manifestation in the age group from 1 to

*Corresponding Author: frageh2002@hotmail.com 
59 years old was $2.9 \%^{(1)}$. Cirrhosis is considered the most advanced stage of chronic liver disease, with variable degrees of hepatic dysfunction and impaired portal hemodynamics. Cirrhotic patients may be asymptomatic, compensated or decompensated. Those decompensated patients suffer from serious complications which influence the disease's prognosis(2). Advanced liver cirrhosis is considered as lifethreatening disorder with limited treatment options(3). Hyponatremia is definite when serum sodium level less $130 \mathrm{mEq} / \mathrm{L}$. It is a frequent observation in patients with cirrhosis, showing a relationship with various clinical manifestations and a poor prognosis $(4,5)$. The pathophysiology of hyponatremia is based on systemic hemodynamic abnormalities caused by impairment in the renal capacity to eliminate solute-free water that causes retention of water that is disproportionate to the retention of sodium, thus causing a reduction in serum sodium concentration and hypo-osmolality. The main pathogenic factor responsible for hyponatremia is a non-osmotic hypersecretion of arginine vasopressin (or antidiuretic hormone) from the neurohypophysis related to circulatory dysfunction ${ }^{(6,7)}$. Since the systemic circulation may be affected by portal hypertension due to the increased intrahepatic resistance, the hyperdynamic state and the development of collateral vessels suggests a close link between portal hemodynamics and hyponatremia( ${ }^{(2,8)}$. Doppler US allows the real-time observation of blood flow under physiological conditions. Investigators have reported the efficacy of this technique for evaluating portal hemodynamics in cirrhotic patients. It is safe, minimally invasive procedure, economical and widely available $(9,10)$. Despite increase in prevalence of liver diseases, the published data and research articles from Egypt about the relationship between impact of portal hemodynamic changes and hyponatremia on the prognosis of cirrhosis are still deficient, so the study aimed to assess role of portal hemodynamic changes in the prediction of mortality and adverse outcome in hyponatremic cirrhotic patients.

\section{Subjects and Methods}

This cross-sectional study was conducted in Tropical Medicine Department at Zagazig university hospitals during two years from July 2018 to July 2020. Eighty patients ( $>18$ years) with post viral hepatitis liver cirrhosis with hyponatremia serum sodium $<130$ $\mathrm{mEq} / \mathrm{L}$ were included in the study. They were diagnosed on clinical basis aided by laboratory and radiological investigations.

Exclusion criteria:

Patients receiving direct acting antiviral drugs (DAAs) for HCV within 6 months, or those with history of drugs, procedure, operation, or condition that affect portal hemodynamics e.g., Transjuglar Intrahepatic Portosystemic Shunts or shunt operation or portal vein thrombosis. Patients with malignancy including hepatocellular carcinoma and those with history of cardiac or renal diseases were also excluded from the study. All patients were subjected to the following Personal history and clinical examinations. Diagnosis of hepatic encephalopathy using West Haven criteria ${ }^{(11)}$. Laboratory investigations were done: Complete blood count (CBC) by system XKX21 from Roche diagnosis, liver function tests (LFT) and renal function tests by Cobas c 702, coagulation pro- 
files (PT and INR) by using Sysmex, CS2100i, and viral markers: $\mathrm{HBs} \mathrm{Ag}$ and anti HCV Ab also by using Cobas e 602. In addition to that, serum electrolytes i.e., sodium, potassium, chloride, and calcium were estimated by using Cobas ISE; Cobas c 702 module- Roche Diagnostics

Modified Child's classification and Model of End Stage Liver disease (MELD) and MELDNa score were calculated as follow:

Model for End-Stage Liver Disease (MELD) = $3.78 \times$ in [serum bilirubin $(\mathrm{mg} / \mathrm{dL})]+11.2 \times$ in [INR] $+9.57 \times$ in [serum creatinine $(\mathrm{mg} / \mathrm{dL})$ ] +6.43 . (NB: MELD score is reported as a whole number; so, result of the equation above was rounded; MELD-Na score = MELD score - Serum Na mmol/L (0.025 * MELD score * $(140-$ Serum Na) $)+140)^{(12,13)}$.

Grading of esophageal varices (OV)

Upper gastrointestinal endoscopy was performed, and esophageal varices (OV) were graded according to Paquet classification: Grade o: No Varices. Grade I: small varices located in distal oesophagus or oesophagogastric junction and disappear with insufflations. Grade II: One or two small varices located in the distal oesophagus, not disappear with insufflations. Grade III: Mediumsized varices of any number, occupying less than $1 / 3$ of the esophageal lumen. Grade IV: Large, tortuous, or grape-like shape varices occupying more than $1 / 3$ of the esophageal lumen ${ }^{(14) ;}$ while Portal hypertensive gastropathy was graded as follow: PHG grade l: Mild reddening and congestive mucosa, no mosaic pattern. PHG grade II: Redness severe with fine reticular pattern separating areas of raised edematous mucosa having mosaic like pattern or fine speckling. PHG grade III: Point bleeding + grade II(15).

\section{Abdominal US examination}

Doppler study of portal circulation was done using Doppler US model with colored and pulsed Doppler capability using a (Sonoscap S11) with a $3.75 \mathrm{MHz}$ convex probe and expert operator. Patients lie in the supine position after fasting for 4 hours or more. In every patient: Portal vein diameter $(\mathrm{mm})$ and Portal vein flow velocity (cm/sec) were measured with the sampling point at a width corresponding to the diameter of the vessel and at an angle less than 60 degrees between the US beam and the vessel. In colored Doppler, normal portal vein exhibits monophasic, low velocity flow and slight respiratory variation. In normal individuals, the portal vein diameter can vary from $<13 \mathrm{~mm}$ in quiet respiration to $16 \mathrm{~mm}$ in deep inspiration, as measured where the portal vein crossed anteriorly to inferior vena $\operatorname{cava}^{(16)}$. The mean velocity $(\mathrm{cm} / \mathrm{s})$ was calculated by automatic tracing of the wave spectrum, for approximately one cardiac cycle, by integration of the time-based average value of the spectrum in the portal trunk. The velocity in the portal vein is approximately $15-18 \mathrm{~cm} / \mathrm{sec}$ with a lot of variation in the range. The velocity decreases in cases where there is increased resistance to the portal blood flow as postulated $^{(17)}$. The mean flow volume $(\mathrm{mL} / \mathrm{min})$ was calculated by multiplying the mean flow velocity for 1 second by cross-section of the vessel, and after that multiplying the calculated value parameter by 60 seconds(18). LC assessed by abdominal US, Aspartate Aminotransferase "AST" to Platelet ratio index APRI and FIB-4. APRI and FIB-4 score was calculated for all patients according to the following equations APRI $=[$ (AST level/ULN)/platelet count $\left.\left(10^{9} / \mathrm{L}\right)\right] \times 100$. To detect cirrhosis; a cutoff score of or more than three and half is diagnostic ${ }^{(19)}$. The FIB4 score for staging of liver fibrosis calculated by the following formula: FIB-4= [age $\times$ AST/platelet count $\left.\left(10^{9} / \mathrm{L}\right) \times \mathrm{VALT}\right]$, threshold value greater than two and half is diag- 
nostic ${ }^{(20)}$. The normal upper limit of normal (ULN) of both ALT (alanine aminotransferase) and AST is equal or less than $40 \mathrm{IU} / \mathrm{L}^{(21)}$.

\section{Ethical consideration}

Approval was taken from both Zagazig University and Suez Universities ethical committee also informed consent was taken from persons included in the study with explanation of study procedures.

\section{Statistical Analysis}

Data were analyzed with SPSS; version 25 (statistical package for the Social Science, Chicago, IL). Quantitative data expressed as mean and standard deviation (SD), normally distributed data were analyzed by independent sample $t$ test and abnormally distributed data were analyzed by Mann Whitney test. Qualitative data expressed as number and percentage and analyzed by Chi square $\left(\mathrm{X}^{2}\right)$ test. Correlation estimated by using Pearson correlation test. The receiver operating characteristic (ROC) curve and $95 \%$ confidence interval $(\mathrm{Cl})$ was performed to determine cutoff values for different studied parameters. All of Sensitivity, specificity, positive predictive value (PPV) and negative predictive value (NPV) were determined. P-value significant if $<0.05$ and highly significant if $<0.001$.

\section{Results}

Eighty patients 63 males (78.8\%) and 17 females (21.2\%) with post viral hepatitis liver cirrhosis with hyponatremia serum $\mathrm{Na}<130$ $\mathrm{mEq} / \mathrm{L}$ were included in the study, with age ranging from 38 to 62 years and mean 50.1 \pm 6.5 . Their history, clinical, laboratory, abdominal US, upper GIT endoscopy and
Doppler US data were presented in table (1). In fig. 1, serum Na has a highly statistically significant negative correlation with modified Child-Pugh score (a) $(r=-0.400, P$ $<0.001)$ and with MELD score (b) ( $r=-0.394$, $\mathrm{P}<0.001)$. Table $(2 \mathrm{a})$ clarified that most of the patients developed hepatic encephalopathy $\mathrm{HE}$, spontaneous bacterial peritonitis SBP, hepato-renal syndrome HRS and mortality. Hepatic encephalopathy is highly statistical- ly significant with portal hemodynamic changes markers, portal vein congestive index is statistically highly significant in Hepato-renal syndrome and bleeding esophageal varices Table (2b). In Table (3), apart from Hepatic A restrictive index, RI which showed significance difference be- tween the non-survived and survived patients, the difference in MELD score, MELD- Na score, and portal vein $\mathrm{Cl}$ between the non-survived and the survived patients was statistically insignificant. Figure 2: Analysis of the receiver operating characteristic (ROC) curve and 95\% confidence interval $(\mathrm{Cl})$ revealed that Area under the ROC curve of the studied parameters were as the following: (a) MELD score was 0.670 (0.51-0.83), (b) MELD-Na score was 0.602 (0.44-0.76), (c) portal vein $\mathrm{Cl}$ was 0.711(0 .56-0.86); (d) while Hepatic A. $\mathrm{RI}$ was 0.712 (0.410-0.814). As regard the predictive validity of MELD, MELD-Na, portal vein $\mathrm{Cl}$ and Hepatic $\mathrm{A}$. RI for mortality in hyponatremia patients; At cut off values of MELD score $>21$, MELD-Na score $>32$, PV congestive index $>0.089$ and hepatic $A$ resistive Index $>0.82$. Portal vein $\mathrm{Cl}$ was the most sensitive indicator $78.5 \%$ and hepatic A RI was the most specific indicator (specificity $70.8 \%$ ) for prediction of mortality in hyponatremia patients (Table 4). 


\begin{tabular}{|c|c|}
\hline \multicolumn{2}{|c|}{$\begin{array}{c}\text { Table 1: Patient's Past History, laboratory, } \\
\text { and Radiological investigations }\end{array}$} \\
\hline Parameters & $\begin{array}{l}\text { Hyponatremias' } \\
\text { Patients } \\
(\mathrm{N}=80)\end{array}$ \\
\hline $\begin{array}{l}\text { History of } \\
\text { Diabetes Mellitus } \\
\text { Bilharziasis } \\
\text { upper GIT bleeding } \\
\text { variceal treatment } \\
\text { hepatic encephalopathy }\end{array}$ & $\begin{array}{l}36(45 \%) \\
33(41.3 \%) \\
27(33.8 \%) \\
34(42.5 \%) \\
39(48.8 \%)\end{array}$ \\
\hline $\begin{array}{l}\text { Laboratory Parameters } \\
\text { WBCs }\left(\times 10^{9} / \mathrm{L}\right) \\
\text { Hemoglobin }(\mathrm{g} / \mathrm{dl}) \\
\text { Platelet }\left(\text { cell } \times 10^{9} / \mathrm{L}\right) \\
\text { Total bilirubin }(\mathrm{mg} / \mathrm{dl}) \\
\text { Serum albumin }(\mathrm{g} / \mathrm{dl}) \\
\text { INR } \\
\text { Creatinine }(\mathrm{mg} / \mathrm{dl}) \\
\text { Sodium }(\mathrm{mEq} / \mathrm{L}) \\
\text { Potassium }(\mathrm{mEq} / \mathrm{L}) \\
\text { Calcium }(\mathrm{mg} / \mathrm{dL}) \\
\text { Chloride }(\mathrm{mEq} / \mathrm{L}) \\
\text { Modified Child score } \\
\text { MELD }\end{array}$ & $\begin{array}{c}3.1 \pm 1.3 \\
9.5 \pm 2.1 \\
94.4 \pm 49 \\
2.1 \pm 1.3 \\
2.7 \pm 0.5 \\
1.7 \pm 0.4 \\
1.5 \pm 0.7 \\
122.5 \pm 5.8 \\
3.6 \pm 0.5 \\
9.5 \pm 1 \\
98.9 \pm 4.5 \\
11.2 \pm 2.4 \\
18.1 \pm 6.8\end{array}$ \\
\hline $\begin{array}{l}\text { Causes of liver Cirrhosis: } \\
\text { HCV } \\
\text { HBV } \\
\text { HCV \& HBV }\end{array}$ & $\begin{array}{c}70(88.5 \%) \\
4(5 \%) \\
6(7.5 \%) \\
\end{array}$ \\
\hline $\begin{array}{l}\text { Ultrasonographic Parameters } \\
\text { Shrunken Liver } \\
\text { PV diameter }(\mathrm{cm}) \\
\text { Splenomegaly } \\
\text { Collaterals } \\
\text { Ascites } \\
\end{array}$ & $\begin{array}{l}55(68.7 \%) \\
1.6 \pm 0.23 \\
73(91.2 \%) \\
57(71.3 \%) \\
73(91.3 \%)\end{array}$ \\
\hline $\begin{array}{l}\text { Endoscopic Parameters } \\
\text { Oesophageal varices (OV) } \\
\text { No } \\
\text { Grade I } \\
\text { Grade II } \\
\text { Grade III } \\
\text { Grade IV } \\
\end{array}$ & $\begin{array}{l}15(18.7 \%) \\
7(8.8 \%) \\
23(28.7 \%) \\
21(26.3 \%) \\
14(17.5 \%)\end{array}$ \\
\hline $\begin{array}{l}\text { Portal Hypertensive Gastropathy } \\
\text { Yes } \\
\text { No }\end{array}$ & $\begin{array}{l}50(62.5 \%) \\
30(37.5 \%)\end{array}$ \\
\hline $\begin{array}{l}\text { Doppler Parameters } \\
\text { PV mean velocity }(\mathrm{cm} / \mathrm{s}) \\
\text { Mean flow volume }(\mathrm{ml} / \mathrm{min})\end{array}$ & $\begin{array}{c}10.6 \pm 2.8 \\
960.1 \pm 232.9\end{array}$ \\
\hline $\begin{array}{c}\text { Direction of flow in PV } \\
\text { Hepatopedal } \\
\text { Hepatofugal }\end{array}$ & $\begin{array}{c}9(11.3 \%) \\
71(88.8 \%)\end{array}$ \\
\hline
\end{tabular}

\begin{tabular}{|c|c|}
\hline $\begin{array}{l}\text { PV congestive index }(\mathrm{Cl}) \\
\text { Hepatic A resistive Index (RI) }\end{array}$ & $\begin{array}{l}0.093 \pm .019 \\
0.78 \pm 0.072\end{array}$ \\
\hline $\begin{array}{l}\text { NB: In upper GIT endoscopy ther } \\
\text { gastric varices either solitary } \\
\text { Hepatitis C Virus (HCV), Hepatiti } \\
\text { Blood Cells (WBCS), Internatio } \\
\text { (INR), Model for End-Stage Liver } \\
\text { sodium (MELD-Na), Portal Vein }\end{array}$ & $\begin{array}{l}\text { no patients with } \\
\text { hbined with OV. } \\
\text { us (HBV), White } \\
\text { ormalized Ratio } \\
\text { se (MELD), MELD }\end{array}$ \\
\hline
\end{tabular}

\section{Discussion}

This cross-sectional study included 80 postviral cirrhotic patients with hyponatremia who admitted to the Tropical Medicine Department Zagazig university hospitals. Hyponatremia commonly occurs in the setting of end-stage liver diseases. The study explores the role of portal hemodynamics in mortality and adverse outcome prediction of hyponatremia cirrhotic patients. In this study it is found high statistically significant negative correlation between serum $\mathrm{Na}$ and Child-Pugh score and with MELD score ( $r=-$ $0.400, r=-0.394$ and $p<0.001)$ and this was in line with previous studies(22-24). The association between hyponatremia and severity of cirrhosis is demonstrated by its link with the occurrence of complications, hyponatremia implies an independent predictor for development of complications in cirrhotic patients, adding $\mathrm{Na}$ to MELD score improve short-term mortality prediction among candidates for liver transplantation $^{(25)}$. Splanchnic arterial vasodilatation with reduced systemic vascular resistance leads to reduced mean arterial pressure. It is detected by baroreceptor and leads to activation of compensatory neuro-hormonal mechanisms, including the sympathetic nervous system and renin-aldosterone-angiotensin system, as well as the release of antidiuretic hormone with activation of solute-free water retention, avid renal $\mathrm{Na}$ retention, and dilution hyponatremia. 


\begin{tabular}{|c|c|c|c|}
\hline \multicolumn{4}{|c|}{$\begin{array}{l}\text { Table 2a: complications and mortality among } \\
\text { Hyponatremic cirrhotic patients }(n=80)\end{array}$} \\
\hline \multirow{2}{*}{ Parameters } & \multicolumn{2}{|c|}{ Presence of Complication } & \multirow{2}{*}{$P$ value } \\
\hline & Yes & No & \\
\hline$(\mathrm{SBP})$ & $33(41.2 \%)$ & $47(58.8 \%)$ & 0.02 \\
\hline (HRS) & $20(25.0 \%)$ & $60(75.0 \%)$ & $<0.001$ \\
\hline Bleeding OV & $14(17.5 \%)$ & $66(82.5 \%)$ & $<0.001$ \\
\hline$(\mathrm{HE})$ & $44(55.0 \%)$ & $36(45.0 \%)$ & 0.2 \\
\hline Death & $8(10 \%)$ & $72(90 \%)$ & $<0.001$ \\
\hline
\end{tabular}

\begin{tabular}{|c|c|c|c|c|c|}
\hline \multicolumn{6}{|c|}{$\begin{array}{l}\text { Table 2b: Effect of Portal Hemodynamics on complications } \\
\text { and mortality among the patients }(n=80)\end{array}$} \\
\hline \multicolumn{2}{|c|}{ Parameters } & $\begin{array}{c}\text { MELD } \\
\text { Mean } \pm S D\end{array}$ & $\begin{array}{l}\text { MELD-Na } \\
\text { Mean } \pm \mathrm{SD}\end{array}$ & $\begin{array}{c}\mathrm{PVCl} \\
\text { Mean } \pm \mathrm{SD}\end{array}$ & $\begin{array}{c}\text { HA RI } \\
\text { Mean } \pm \text { SD }\end{array}$ \\
\hline \multirow{3}{*}{ SBP } & Yes & $18.3 \pm 6.6$ & $36.2 \pm 15.3$ & $0.093 \pm 0.017$ & $0.78 \pm 0.07$ \\
\hline & No & $18 \pm 7.2$ & $38 \pm 16$ & $0.092 \pm 0.021$ & $0.77 \pm 0.07$ \\
\hline & $P$ value & 0.84 & 0.62 & 0.65 & 0.84 \\
\hline \multirow{3}{*}{ HRS } & Yes & $18 \pm 7.2$ & $38.6 \pm 16.1$ & $0.0965 \pm 0.002$ & $0.77 \pm 0.01$ \\
\hline & No & $18.2 \pm 6.8$ & $36.9 \pm 15.6$ & $.0915 \pm 0.001$ & $0.75 \pm 0.01$ \\
\hline & $P$ value & 0.90 & 0.68 & $<0.001$ & $<0.001$ \\
\hline \multirow{3}{*}{$\begin{array}{c}\text { Bleeding } \\
\text { OV }\end{array}$} & Yes & $18.4 \pm 6.7$ & $39.2 \pm 15.7$ & $0.0954 \pm 0.002$ & $0.77 \pm 0.08$ \\
\hline & No & $18.1 \pm 7$ & $36.9 \pm 15.7$ & $0.0915 \pm 00.001$ & $0.78 \pm 0.07$ \\
\hline & $P$ value & 0.89 & 0.61 & $<0.001$ & 0.85 \\
\hline \multirow{3}{*}{ HE } & Yes & $21.4 \pm 7$ & $44.9 \pm 16.1$ & $0.102 \pm 0.02$ & $0.77 \pm 0.08$ \\
\hline & No & $18.1 \pm 4.3$ & $36 \pm 8.6$ & $0.081 \pm 0.01$ & $0.75 \pm 0.07$ \\
\hline & $P$ value & $<0.001$ & $<0.001$ & $<0.001$ & $<0.001$ \\
\hline \multirow{3}{*}{ Death } & Died & $20.9 \pm 6.0$ & $39.4 \pm 15.6$ & $0.103 \pm 0.019$ & $0.80 \pm 0.07$ \\
\hline & Survived & $17.8 \pm 6.9$ & $37 \pm 15.8$ & $0.092 \pm 0.019$ & $0.77 \pm 0.07$ \\
\hline & P value & 0.41 & 0.96 & 0.83 & 0.65 \\
\hline
\end{tabular}

$p<0.05=$ significant; $p<0.001=$ highly significant

These compensatory neuro-hormonal mechanisms correlate directly with the degree of portal hypertension. Therefore, serum sodium could be a reasonable parameter that reflects the severity of portal hypertension(26). Some of the patients developed bleeding OV, SBP, HE and HRS ended by mortality in
$10 \%$ of the studied patients. Our results go in hand with those of Angeli et al(22), Kim et $\mathrm{al}^{(23)}$, Amalan et al.(27) and Reddy et al(24). These complications are common in hyponatremia patients except for HRS in which Kim et al (23) did not find significant relationship between it and hyponatremia. 


\begin{tabular}{|l|c|c|c|}
\hline \multicolumn{3}{|c|}{$\begin{array}{c}\text { Table 3: MELD score, MELD-Na score, portal vein Cl and } \\
\text { Hepatic A RI among Dead and survived patients }\end{array}$} \\
\hline \multirow{3}{*}{ Parameters } & \multicolumn{2}{|c|}{ Hyponatremic group } & \multirow{2}{*}{ P value } \\
\cline { 2 - 3 } & Non- survived (8) & Survived (72) & \\
\cline { 2 - 3 } & Mean \pm SD & Mean \pm SD & \\
\hline MELD & $20.9 \pm 6.0$ & $17.8 \pm 6.9$ & 0.41 \\
\hline MELD-Na & $39.4 \pm 15.6$ & $37 \pm 15.8$ & 0.96 \\
\hline PV congestive index (CI) & $0.103 \pm 0.019$ & $0.092 \pm 0.019$ & 0.83 \\
\hline Hepatic A resistive Index (RI) & $0.80 \pm 0.07$ & $0.76 \pm 0.05$ & $0.04 *$ \\
\hline *Significant & & & \\
\end{tabular}

Intervention at different levels of the disease (either improving the microcirculation or the liver's response to damage) can leads to improvements in portal hypertension and its complications $^{(27)}$. In cirrhosis, hyponatremia generally develops slowly and gradually. Therefore, the brain can adjust to hypo- osmolality and hypo-tonicity of the extracellular fluid. However, due to the concomitant abnormalities in nitrogen metabolism, symptoms amenable to hyponatremia are often associated with and hardly distinguishable from those related to $\mathrm{HE}^{(25)}$. This could explain why HE was present in $55 \%$ of our patients.

\begin{tabular}{|l|c|c|c|c|c|}
\hline \multicolumn{6}{|c|}{ Table 4: The validity of MELD, MELD-Na, portal vein Cl and } \\
Hepatic A. RI as a predictor factor for mortality in hyponatremia patients \\
\hline Parameter & Cut-off value & Sensitivity & Specificity & PPV & NPV \\
\hline MELD & 21 & $62.5 \%$ & $68.1 \%$ & 50 & 54.5 \\
\hline MELD-Na & 32 & $62.5 \%$ & $56 \%$ & 50 & 44.8 \\
\hline PV congestive index (CI) & 0.089 & $78.5 \%$ & $56.5 \%$ & 62.8 & 45.4 \\
\hline Hepatic A RI & 0.82 & $63 \%$ & $70.8 \%$ & 50.4 & 56.6 \\
\hline
\end{tabular}

Biggins et al found that $\mathrm{HE}$ is common complication among cirrhotic patients with hyponatremia(26), which agree with the study results and this explained as follow: association between $\mathrm{HE}$ and low serum sodium could be explained based on that advanced liver parenchymal failure among patients with serum sodium < $130 \mathrm{meq} / \mathrm{l}$ probably reflects compensatory osmoregulatory system against cellular swelling due to a combination of high intracellular glutamine, as a consequence of hyperammonia and low extracellular sodium ${ }^{(27)}$. In the present study, apart from Hepatic A. $\mathrm{RI}$, the difference in MELD score, MELD-Na score, and portal vein $\mathrm{Cl}$ between the non- survived and survived patients was statistically insignificant. Validity of MELD, MELD$\mathrm{Na}$, portal vein $\mathrm{Cl}$ and Hepatic $\mathrm{A}$. $\mathrm{RI}$ in the present study as a predictor factor for mortality and hepatic encephalopathy in hyponatremia patients revealed that Portal vein $\mathrm{Cl}$ at cut off value $>0.089$ was the most sensitive indicator (sensitivity $=78.5 \%$ ) and hepatic A RI cut off value $>0.82$ was the most specific indicator (specificity $=70.8 \%$ ) for prediction of mortality. These results agreed with Awwaad et al, 2019(28) who found that hyponatremia patients had statistically significant portal hemodynamic changes with increased morbidity and mortality among them. This could provide new insights on 
novel targetable molecular pathways and metabolites that may affect the outcome in such patients ${ }^{(29)}$. The result findings agree with Ennaifer et al who found that serum $\mathrm{Na}$ $\leq 130 \mathrm{mmol} / \mathrm{L}$ was strongly associated with severity of liver function impairment as indicated by Child-Pugh C (OR=7.84, $\mathrm{p}<0.001)$, and MELD score $>16(\mathrm{OR}=6.76 ; \mathrm{p}=0.001)^{(30)}$.

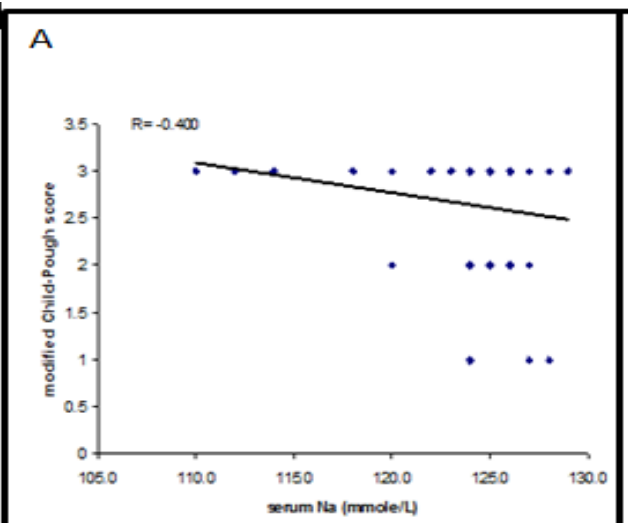

B

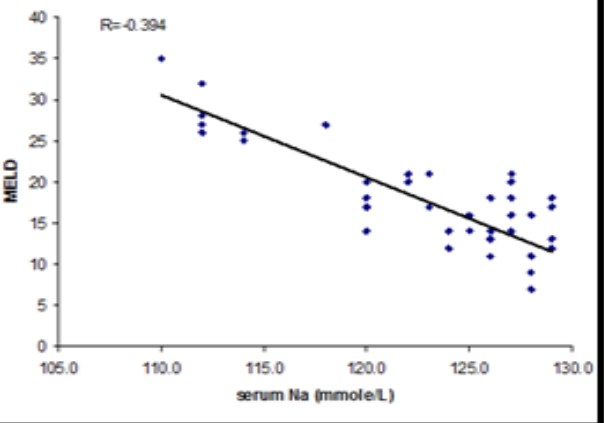

Figure 1: Correlation between serum sodium and modified Child-Pugh score and MELD score

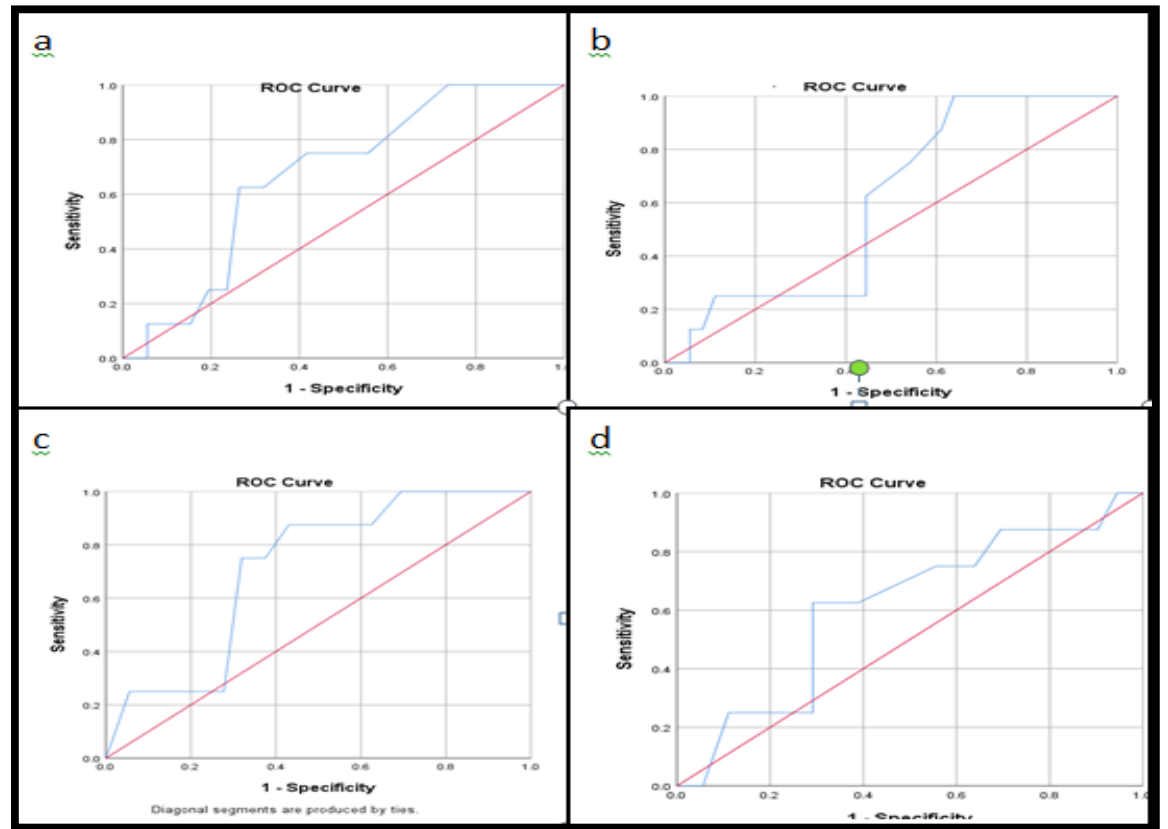

Figure 2: The receiver operating characteristic (ROC) curve of MELD score, MELD-Na, portal vein $\mathrm{Cl}$ and Hepatic A RI as predictors for mortality

Scores obtained by the combinations of measuring portal vein blood velocity, portal vein diameter, the hepatic artery resistance index and splenic artery resistance index were proposed and demonstrated to be use- ful in the clinical monitoring of patients with cirrhosis and portal hypertension(31). Finally, combined usage of Doppler abdominal US as a non-invasive, cheap reliable method to other models may add to prediction of mortality 
in hyponatremic cirrhotic patients, we concluded that portal vein $\mathrm{Cl}$ and hepatic A. RI can be used in prediction of mortality in cirrhotic hyponatremic patients.

\section{Funding: None}

\section{Conflict of interest: None}

\section{References}

1. Alboraie $M$, Youssef $N$, Sherief $A F$, et al. Egyptian liver library: An indexed database for liver disease evidence in Egypt Systematic review, Ar J Gastroenterol, 2019;20(2):109-113.

2. Fortune B, and Cardenas A. Ascites, refractory ascites, and hyponatremia in cirrhosis. Gastroenterol Rep. 2017;5(2): 104-112.

3. Yass P. The global burden of liver disease: A challenge for methods and for public health. BMC Medicine. 2014;12(1): 159. doi: 10.1186/s12916-014-0159-5.

4. Alukal J, John S, Thuluvath P. Hyponatremia in Cirrhosis: An Update. Am J Gastroenterol. 2020;115(11):1775-1785.

5. Ahluwalia V, Heuman DM, Feldman G, et al. Correction of hyponatraemia improves cognition, quality of life, and brain oedema in cirrhosis. J hepatol. 2015;Jan 1; 62(1):75-82.

6. Prohic D, Mesihovic R, Vanis N, et al. Prognostic significance of ascites and serum sodium in patients with low meld scores. Med Arch. 2016;70(1): 48- 52.

7. Gianotti RJ, and Cardenas A. Hyponatraemia and cirrhosis. Gastroenterol report. 2014; Feb 1; 2(1):21-6.

8. Sanyal AJ, Bosch J, Blei A, et al. Portal hypertension and its complications. Gastroenterology. 2008; May 1; 134(6):1715-28.

9. Bolondi LU, Gaiani S, Barbara L editors. Doppler flowmetry in portal hypertension. In Innovations in Abdominal
Ultrasound. 1992: 49-60. Springer, Berlin, Heidelberg.

10. Baik SK. Haemodynamic evaluation by Doppler ultrasonography in patients with portal hypertension:a review. Liver Inter. 2010; Nov; 30(10):1403-13.

11. Vistrup H, AModio P, Bajaj J, et al (2014). Hepatic encephalopathy in chronic liver disease: Practice Guideline by the American Association for the Study of Liver Diseases and the European Association for the Study of the Liver. Hepatology. 2014;60(2):715-35.

12. Gagandeep A, Rajeev M K, Rohit G., et al .Child-Turcotte-Pugh Score, MELD Score and MELD-Na Score as Predictors of Short-Term Mortality among Patients with End-Stage Liver Disease in Northern India, Inflamm Intest Dis. 2020 Feb; 5(1): 1-10.

13. Freeman RB, Wiesner RH, Harper A. The new liver allocation system: moving toward evidence-based transplantation policy. Liver Transplantation. 2002; 8:851.

14. Paquet KJ. Prophylactic endoscopic sclerosing treatment of the esophageal wall in varices-a prospective controlled randomized trial. Endoscopy. 1982;14 (01):4-5.

15. Pungpapong S, Keaveny A, Raimondo M. Accuracy and interobserver agreement of small-caliber vs. conventional esophagogastroduodenoscopy for evaluating esopha-geal varices. Endoscopy. 2007;39 (08):673-780.

16. Geleto G, Getnet W, Tewelde T. Mean normal portal vein diameter using sonography among clients coming to radiology department of Jimma University Hospital, Southwest Ethiopia. Ethiop J health Sci. 2016; 26(3):237-242.

17. Afif AM, Chang JP, Wang YY. A sonographic Doppler study of the hepatic vein, portal vein and hepatic artery in liver cirrhosis: Correlation of hepatic hemodynamics with clinical 
Child Pugh score in Singapore. Ultrasound. 2017;25(4):213-221.

18. Mariana Lazo. Liver Function - Johns Hopkins Diabetes Guide. Available at: https://www.hopkinsguides.com/hopkin s/view/Johns_Hopkins_Diabetes_Guide/ 547086/all/Liver function. Last retrived 11/6/2020.

19. Martínez SM, Crespo G, Navasa M, et al. Noninvasive assessment of liver fibrosis. Hepatology. Jan; 2011;53(1):325-35. PMID: 21254180.

20. Mansour-Ghanaei, F. Decreased Serum Total T3 Level in Hepatitis B and C Related Cirrhosis by Severity of Liver Damage. Ann Hepatol. 2012;11: 667-671.

21. Maruyama H, Kobayashi K, Kiyono S, et al. Interrelationship between insulin resistance and portal haemodynamic abnormality in cirrhosis. Int J Med Sci; 2017;14(3):240-245.

doi:10.7150/ijms.17738. Available from https://www.medsci.org/v14p0240.htm

22. Angeli $\mathrm{P}$, Wong $\mathrm{F}$, Watson $\mathrm{H}$, et al. Hyponatremia in cirrhosis: results of a patient population survey. Hepatology. 2006;Dec; 44(6):1535-42.

23. Kim JH, Lee JS, Lee $\mathrm{SH}$, et al. The association between the serum sodium level and the severity of complications in liver cirrhosis. Korean J Intern Med. 2009;Jun; 24(2):106.

24. D. Dinesh Kumar Reddy, C.S.S.Sarma, Madhavi. Study of hyponatremia in cirrhosis of liver and its prognostic
Value. JMSCR. 2019;March; 7(3): 487493.

25. Leise $M$, and Cárdenas A. Hyponatremia in cirrhosis: implications for liver transplantation. Liver Transpl. 2018; 24(11): 1612- 1621.

26. Biggins SW, Rodriguez HJ, Bacchetti $P$, et al. Serum sodium predicts mortality in patients listed for liver transplantation. Hepatology. 2005;Jan; 41(1):32-9.

27. Christudhas AV, Venu I, Sivakumar SR, et al. Clinical Study of Association between the Serum Sodium level and Severity of complication in Liver Cirrhosis at Kanyakumari government medical college. Int. J. Adv. Res. 2018;Oct; 6(10): 369-374.

28. Awwaad SA, Elbadrawy EG, Hussein HI, et al. Portal Hemodynamics in Hyponatremic Egyptian Cirrhotic Patients. Afro-Egypt J Infect Endem Dis 2019; 9 (4): 260-269 https://aeji.journals.ekb.eg/ http://mis.zu.edu.eg/ajied/home. aspx

29. Vilaseca M, Guixé-Muntet S, FernándezIglesias A, et al. Advances in therapeutic options for portal hypertension. Thera adv Gastroenterol. 2018; Nov; 11: 1756284818811294.

30. Ennaifer $\mathrm{R}$, Cheikh $\mathrm{M}$, Romdhane $\mathrm{H}$, et al. Hyponatremia in cirrhosis: Risk factors and prognostic value. Tunis Med. 2016; May; 94(5):401-405.

31. Bolognesi M, Di Pascoli M, Sacerdoti D. Clinical role of non-invasive assessment of portal hypertension. WJG. 2017; Jan 7; 23(1):1. 